\title{
Dielectric Properties of Calcium Phosphate Ceramics
}

\section{Omer KAYGILI ${ }^{1}$ *, Serhat KESER ${ }^{2}$, Tankut ATES ${ }^{1}$, Sevda KIRBAG ${ }^{3}$, Fahrettin YAKUPHANOGLU ${ }^{1}$}

\author{
${ }^{1}$ Department of Physics, Faculty of Science, Firat University, Elazig 23119, Turkey \\ ${ }^{2}$ Department of Chemistry, Faculty of Science, Firat University, Elazig 23119, Turkey \\ ${ }^{3}$ Department of Biology, Faculty of Science, Firat University, Elazig 23119, Turkey \\ ref http://dx.doi.org/10.5755/j01.ms.22.1.7222
}

Received 31 May 2014; accepted 19 September 2014

\begin{abstract}
Calcium phosphate ceramics with various $\mathrm{Ca} / \mathrm{P}$ ratios of $1,2,3,4$ and 8 were synthesized via sol-gel route. The effects of $\mathrm{Ca} / \mathrm{P}$ molar ratio on structural, morphological and dielectric properties were investigated in detail using X-ray diffraction (XRD), Fourier transform infrared (FTIR) spectroscopy, scanning electron microscopy and dielectric measurements. The $\mathrm{Ca} / \mathrm{P}$ molar ratio significantly affects the crystal structure and phase composition. The crystallite size, lattice parameters and volume of the unit cell were remarkably affected by the change in the $\mathrm{Ca} / \mathrm{P}$ molar ratio. The microstructure is changed with increasing the $\mathrm{Ca} / \mathrm{P}$ molar ratio. The relative permittivity and alternating current conductivity gradually decrease for the samples having the $\mathrm{Ca} / \mathrm{P}$ ratios higher than 2 . The dielectric loss decreases gradually with the increase of the molar ratio of $\mathrm{Ca} / \mathrm{P}$.

Keywords: calcium phosphates, crystal structure, dielectric properties.
\end{abstract}

\section{INTRODUCTION}

Undoubtedly calcium phosphate $(\mathrm{CaP})$ ceramics are one of the most important materials used in biotechnology and medical fields as bone substitutes due to their excellent biocompatibilities and similar compositions to bone mineral. The CaPs are classified as hydroxyapatite (HAp, $\left.\mathrm{Ca}_{10}\left(\mathrm{PO}_{4}\right)_{6}(\mathrm{OH})_{2}\right)$, tricalcium phosphate $\left(\mathrm{TCP}, \mathrm{Ca}_{3}\left(\mathrm{PO}_{4}\right)_{2}\right)$, tetracalcium phosphate (TTCP, $\left.\mathrm{Ca}_{4}\left(\mathrm{PO}_{4}\right)_{2} \mathrm{O}\right)$, octacalcium phosphate (OCP, $\left.\mathrm{Ca}_{8} \mathrm{H}_{2}\left(\mathrm{PO}_{4}\right)_{6} .5 \mathrm{H}_{2} \mathrm{O}\right)$, amorphous calcium phosphate (ACP) and biphasic calcium phosphate (BCP) $[1-8]$. The $\mathrm{Ca} / \mathrm{P}$ molar ratio affects the solubility and crystal structure of the CaPs. Namely, the $\mathrm{Ca} / \mathrm{P}$ molar ratios and solubility of the $\mathrm{CaPs}$ are 1.67 and poor for HAp, 1.50 and fair for TCP, 1.15-1.67 and high for ACP, $1.50-1.67$ and variable depending on the TCP/HAp ratio for BCP $[9,10]$. In addition, these compounds are light in weight, chemically stable and resisting to $\mathrm{pH}$ changes, microbial attacks and solvent conditions [11].

In the present study, we synthesized five $\mathrm{CaP}$ ceramics with different $\mathrm{Ca} / \mathrm{P}$ molar ratio of $1,2,3,4$ and 8 and investigated the effects of this ratio on the as-mentioned properties using the experimental analysis techniques of Xray diffraction (XRD), Fourier transform infrared (FTIR) spectroscopy, scanning electron microscopy and dielectric measurements. Hence, we tried to determine the advantages and/or disadvantages of the as-synthesized samples.

\section{EXPERIMENTAL}

All the chemicals used in the synthesis of the calcium phosphates were obtained from Merck and used as received without any purification. Five calcium phosphate

\footnotetext{
* Corresponding author. Tel: +90 424 2370000/3623; fax: +90
} 4242330062. E-mail address: okaygili@firat.edu.tr (O. Kaygili) ceramic samples with the $\mathrm{Ca} / \mathrm{P}$ molar ratio of $1,2,3,4$ and 8 were synthesized by sol-gel method and referred as CP1, CP2, CP3, CP4 and CP8, respectively. Appropriate amounts of calcium nitrate tetrahydrate $\left(\mathrm{Ca}\left(\mathrm{NO}_{3}\right)_{2} \cdot 4 \mathrm{H}_{2} \mathrm{O}\right.$, $\mathrm{CN})$ and diammonium hydrogen phosphate $\left(\mathrm{NH}_{4}\right)_{2} \mathrm{HPO}_{4}$, DAP) were dissolved in distilled water in different beakers. The DAP solution was added drop wise to the $\mathrm{CN}$ solution. The new opaque solution was observed and then mixed at $90{ }^{\circ} \mathrm{C}$ until the gel formation. The gel was dried in an oven at $160{ }^{\circ} \mathrm{C}$ for $36 \mathrm{~h}$ and heated in an electric furnace at $700{ }^{\circ} \mathrm{C}$ for $1.5 \mathrm{~h}$. The white calcium phosphate powders were observed.

The X-ray diffraction (XRD) analyses were performed on a Bruker D8 Advance diffractometer operated at $40 \mathrm{kV}$ and $40 \mathrm{~mA}$ in the $2 \theta$ range from $25^{\circ}$ to $55^{\circ}$. The crystallite size $(D)$ is estimated by the well-known Scherrer equation [12]:

$D=\frac{0.9 \lambda}{\beta \cos \theta}$,

where $\lambda$ is the $X$-ray wavelength, $\beta$ is the full width at half maximum (FWHM) and $\theta$ is known as the Bragg angle. Using the inter-planar spacing $(d)$ values, the lattice parameters $(a$ and $c$ ) and volume of the unit cell $(V)$ are calculated from the following relations for tetragonal and hexagonal crystal systems, respectively.

$\frac{1}{d^{2}}=\frac{h^{2}+k^{2}}{a^{2}}+\frac{l^{2}}{c^{2}}$;

$\frac{1}{d^{2}}=\frac{4}{3}\left(\frac{h^{2}+h k+k^{2}}{a^{2}}\right)+\frac{l^{2}}{c^{2}}$

$V=a^{2} c$

$V=\frac{\sqrt{3}}{2} a^{2} c$

Fourier transform infrared (FTIR) spectra were collected in the interval of $450-4000 \mathrm{~cm}^{-1}$ within a 
spectral resolution of $4 \mathrm{~cm}^{-1}$ using the $\mathrm{KBr}$ pellet method. The morphology was investigated using a JEOL JSM $7001 \mathrm{~F}$ scanning electron microscope (SEM) and the elemental compositions of the investigated areas were determined by an energy dispersive X-ray (EDX) analyzer (Oxford Instruments Inca 350). Dielectric studies were carried out by a HIOKI 3532-50 LCR meter at room temperature. Using the following relations, the relative permittivity $\left(\varepsilon^{\prime}\right)$, dielectric loss $\left(\varepsilon^{\prime \prime}\right)$ and alternating current conductivity $\left(\sigma_{a c}\right)$ values of the samples were estimated $[13,14]$ :

$$
\begin{aligned}
& \varepsilon^{\prime}=\frac{C \times l}{\varepsilon_{o} \times A} ; \\
& \varepsilon^{\prime \prime}=\tan \delta \times \varepsilon^{\prime} ; \\
& \sigma_{a c}=\frac{l}{Z \times A},
\end{aligned}
$$

where $\varepsilon_{o}$ is the permittivity of free space, $A$ is the area of the electrode and $C$ and $l$ are the capacitance and thickness of the sample, respectively. $\tan \delta$ is the loss tangent and $Z$ is the impedance. To understand the conductivity mechanism, in more detail, the following Jonscher relation is used [15]:

$$
\sigma_{a c}=\sigma_{d c}+B \omega^{s} \text {, }
$$

where $\sigma_{d c}$ is the direct current conductivity, $B$ is a constant and $\omega$ is the angular frequency, $s$ is an exponent and estimated from the slope of $\log \sigma_{a c}$ vs. $\log \omega$ plot.

\section{RESULTS AND DISCUSSION}

XRD patterns of the calcium phosphate samples shown in Fig. 1 exhibit the significant changes with varying $\mathrm{Ca} / \mathrm{P}$ molar ratios. As expected, the crystal structure and phase composition were affected by the $\mathrm{Ca} / \mathrm{P}$ molar ratio. For $\mathrm{CP} 1$, the calcium phosphate $\left(\mathrm{Ca}_{2} \mathrm{P}_{2} \mathrm{O}_{7}\right.$, JCPDS no: 71-2123) having the tetragonal crystal structure without any secondary phase was detected. At higher $\mathrm{Ca} / \mathrm{P}$ molar ratios ranging from 2 to 4 , the formation of the dominant phase of hydroxyapatite (HAp, $\mathrm{Ca}_{10}\left(\mathrm{PO}_{4}\right)_{6}(\mathrm{OH})_{2}$, JCPDS no: 09-0432) having the hexagonal crystal structure was observed together with the minor phase of calcium oxide (CaO, JCPDS no: $37-1497$ ) having the cubic crystal system. While the characteristic peaks belonging to (002), (112) and (300) planes of HAp phase were observed at $26.06,31.98$ and $33.08^{\circ}$ for CP2, these peaks were detected at $25.92,31.82$ and $32.98^{\circ}$ for $\mathrm{CP} 3$. A significant shift in the as-mentioned characteristic peaks occurs with increasing $\mathrm{Ca} / \mathrm{P}$ ratio from 2 to 3 . For CP8, while the calcium hydroxide $\left(\mathrm{Ca}(\mathrm{OH})_{2}\right.$, JCPDS no: $81-2040$ ) with the hexagonal crystal structure is the major phase, the HAp is observed as the secondary one. Compared to the stoichiometric value of 1.67, the formation of the HAp phase at $\mathrm{Ca} / \mathrm{P}$ higher molar ratios does not a surprising result. This result supports the reported results related to the formation of the HAp phase synthesized at different $\mathrm{Ca} / \mathrm{P}$ ratio ranging from $3 / 2$ to $10 / 3$ by Pham et al. [16].

The calculated values of the crystallite size $(D)$, lattice parameters $(a$ and $c$ ) and volume of the unit cell are given in Table 1 and the change of these parameters as a function of the $\mathrm{Ca} / \mathrm{P}$ molar ratio are plotted in Fig. 2. All the above mentioned parameters are significantly affected by the $\mathrm{Ca} / \mathrm{P}$ molar ratio. This may be attributed to the phase composition, namely, while the change in these parameters is a very small for the samples with a similar phase composition, the change in the as mentioned parameters except for the crystallite size of CP1 is extremely great for the samples having dissimilar phase composition.

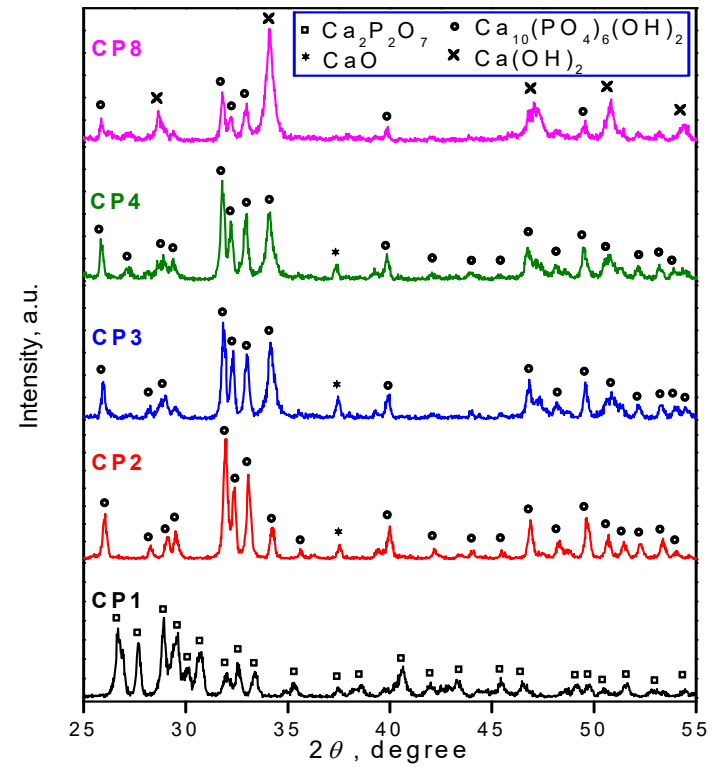

Fig. 1. XRD patterns of the samples

Table 1. The calculated values of the crystallite size, lattice parameters and volume of the unit cell

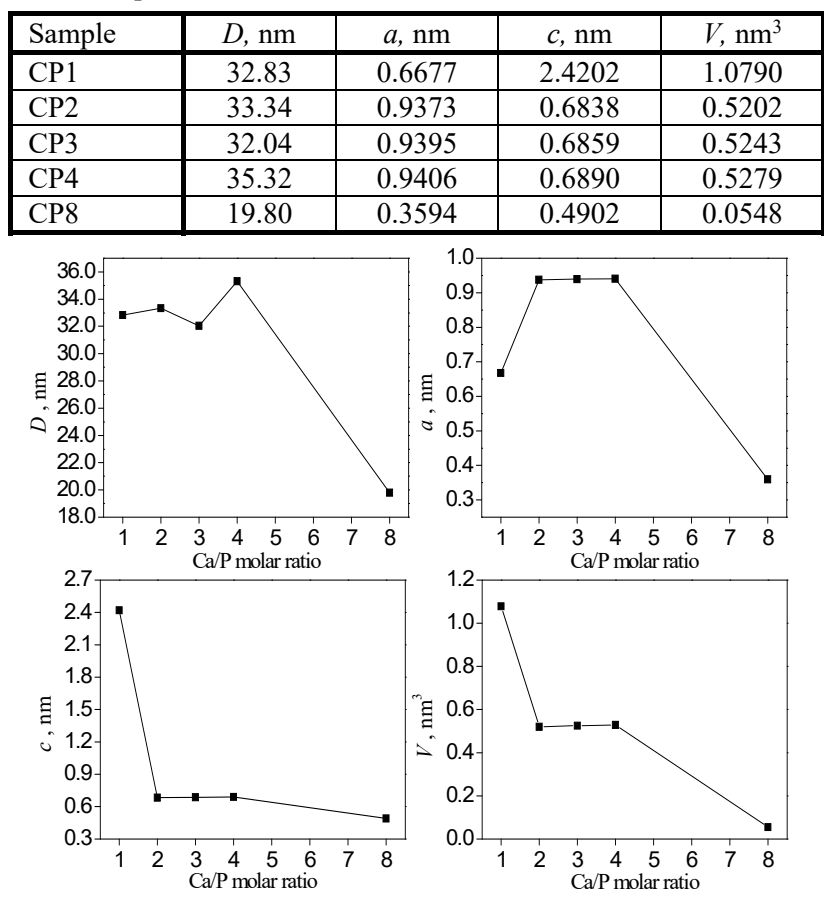

Fig. 2. The crystallite size, lattice parameters of a and $\mathrm{c}$ and volume of the unit cell as a function of $\mathrm{Ca} / \mathrm{P}$ molar ratio

FTIR spectra of all the samples are shown in Fig. 3 and the observed bands are also given in Table 2. The bands observed at about 633 and $3572 \mathrm{~cm}^{-1}$ are related to the vibrational bands of the hydroxyl groups. These bands 
were detected for all the samples except for CP1. The bands related to the phosphate groups were observed at about 560, 570, 602, 1002, 1029, 1045, 1079 and $1090 \mathrm{~cm}^{-1}$. The other bands, which are detected only for $\mathrm{CP} 1$, at 726 and $1136 \mathrm{~cm}^{-1}$ are associated to the stretching modes of $\mathrm{P}_{2} \mathrm{O}_{7}^{4-}$ [17]. These findings verify the $\mathrm{P}_{2} \mathrm{O}_{7}$ based phase identified on the XRD for CP1. The bands at 873, 1420 and $1468 \mathrm{~cm}^{-1}$ are attributed to the vibration modes of the carbonate groups [18]. The bands centered at around 1638,3450 and $3643 \mathrm{~cm}^{-1}$ are assigned to the adsorbed water.

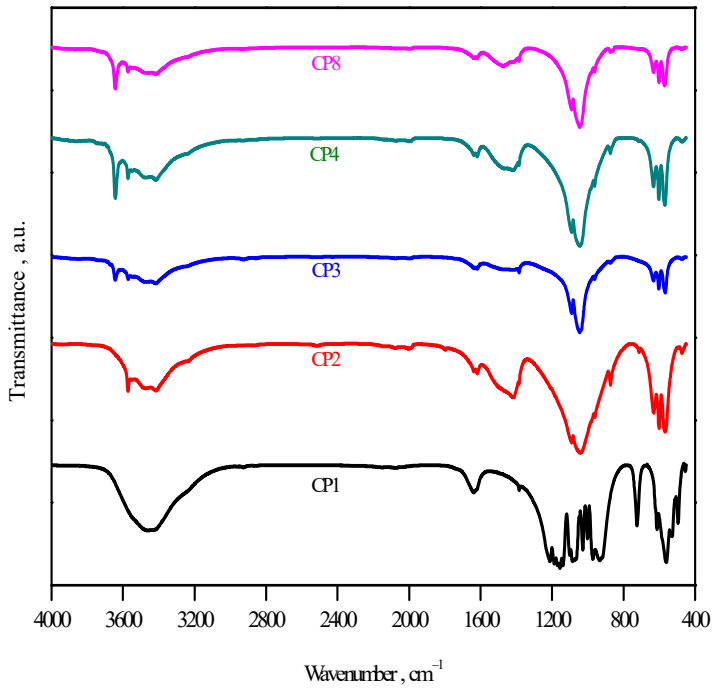

Fig. 3. FTIR spectra of the samples

Table 2. The observed bands belonging to the vibrational modes of the functional groups

\begin{tabular}{|l|c|}
\hline Sample & Bands, $\mathrm{cm}^{-1}$ \\
\hline CP1 & $3450,1638,1211,1156,1136,1079,1029,1002$, \\
& $971,726,613,560,527$ \\
\hline CP2 & $\begin{array}{c}3572,3450,1638,1420,1089,1044,873,632,601, \\
\end{array}$ \\
\hline CP3 & $3644,3572,1638,1090,1046,874,633,603,567$ \\
\hline CP4 & $\begin{array}{c}3643,3572,3450,1638,1420,1090,1045,874,633, \\
603,569\end{array}$ \\
\hline CP8 & $3643,3572,3415,1638,1468,1090,1045,873,633$, \\
& 602,571 \\
\hline
\end{tabular}

As can be seen from the SEM images shown in Fig. 4, the morphology of the samples varies with increasing molar ratio of $\mathrm{Ca}$ to $\mathrm{P}$. As expected, $\mathrm{Ca}$ amount increases and $\mathrm{P}$ content decreases with the increase of the $\mathrm{Ca} / \mathrm{P}$ molar ratio. The theoretical values of the $\mathrm{Ca} / \mathrm{P}$ ratios are 1 , 2, 3, 4 and 8 and their experimental values detected from EDX analyses are 1.08, 1.96, 2.82, 4.19 and 7.69 for CP1, CP2, CP3, CP4 and CP8, respectively. The theoretical and the experimental values are very close to each other namely the EDX results confirm the formation of the calcium phosphates with the desired molar ratio of $\mathrm{Ca} / \mathrm{P}$.

The plots of the relative permittivity as a function of frequency of the samples are illustrated in Fig. 5.

While the changes of the relative permittivity $\left(\varepsilon^{\prime}\right)$ values of CP1 and CP2 have almost the same and these values are about 23 , the $\varepsilon^{\prime}$ values of CP3, CP4 and CP8 are around $16.5,11.5$ and 10.5 , respectively. While the graphs of the relative permittivity vs. frequency of CP1 and $\mathrm{CP} 2$ are very similar to the reported plot belonging to the dry tibia [19], the frequency dependence of the relative permittivity of CP4 and CP8 is so close to the femur [20].

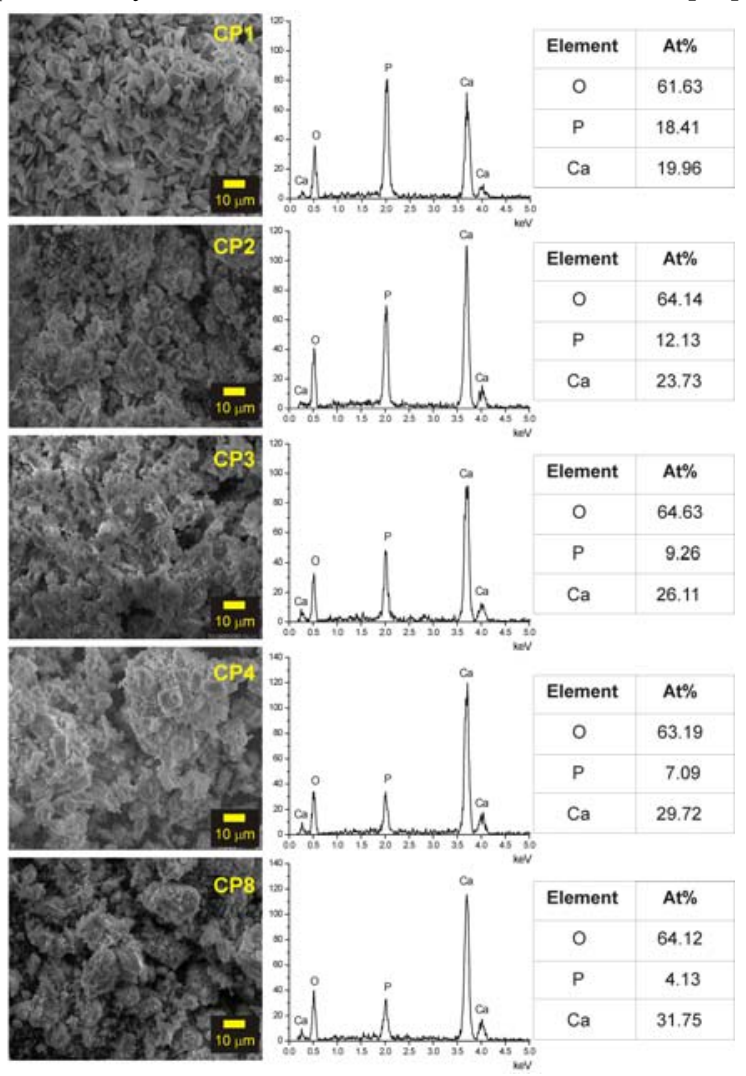

Fig. 4. SEM images and EDX analysis reports of the assynthesized samples

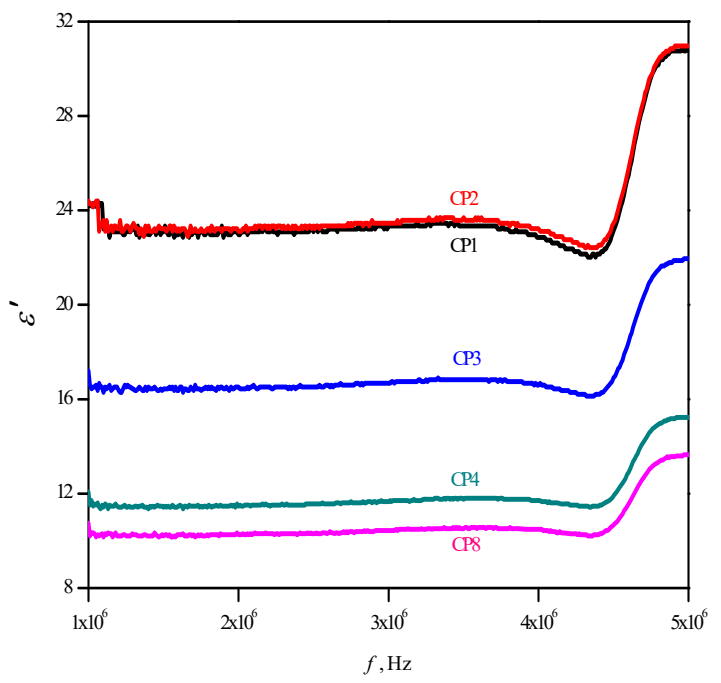

Fig. 5. The plots of the relative permittivity as a function of frequency of as-prepared samples

Moreover, the plots of the relative permittivity as a function of frequency of CP3, CP4 and CP8 are in a good harmony with human cortical bone having different hydration values [21]. At the $\mathrm{Ca} / \mathrm{P}$ molar ratios greater than 2 , the relative permittivity significantly decreases with increasing amount of $\mathrm{Ca}$.

Fig. 6 shows the dielectric loss vs. frequency plots of the samples. For all the samples, the dielectric loss changes with increasing frequency and the maximum dielectric loss 
are observed at about $4.5 \mathrm{MHz}$. Moreover, the dielectric loss significantly decreases with increasing $\mathrm{Ca} / \mathrm{P}$ ratio. Additionally, the relaxation time $\left(\tau_{0}\right)$ values were calculated to be $34.47,34.39,34.39,34.32$ and 34.39 ns for CP1, CP2, CP3, CP4 and CP8, respectively. Namely, it did not observe any remarkable change in the relaxation times.

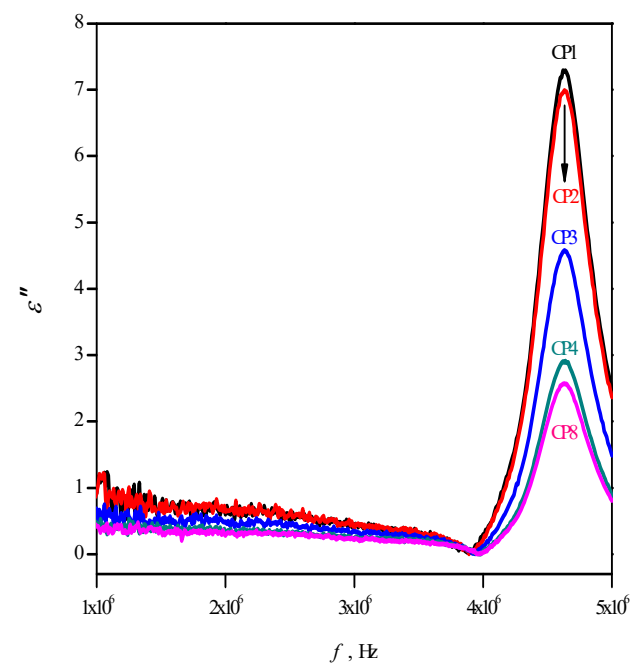

Fig. 6. The change of the dielectric loss with increasing frequency of the as-synthesized samples

The alternating current conductivity $\left(\sigma_{\mathrm{ac}}\right)$ vs. frequency graphs are plotted in Fig. 7. The $\sigma_{\mathrm{ac}}$ values of the samples linearly increase with increasing frequency and affected by the change in the $\mathrm{Ca} / \mathrm{P}$ molar ratio. Although the changes in the alternating current conductivity of CP1 and CP2 are almost close to each other, the $\sigma_{\mathrm{ac}}$ values gradually decrease with increasing of the $\mathrm{Ca} / \mathrm{P}$ molar ratio. According to Nagai and Nishino, the change in the alternating current conductivity of the samples at room temperature may be associated to the migration of $\mathrm{H}^{+}$in adsorbed water $[22,23]$.

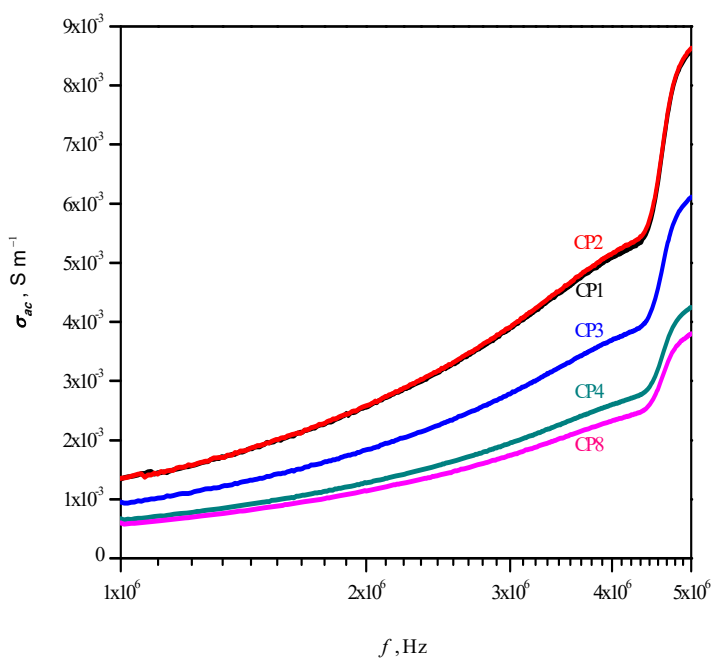

Fig. 7. The alternating current conductivity vs. frequency plots of the samples

The calculated values of $s$ were found to be 0.965 , 0.966, 0.994, 0.995 and 0.981 for CP1, CP2, CP3, CP4 and $\mathrm{CP} 8$, respectively. Except for CP8, the $s$ value gradually increases with the increase of the $\mathrm{Ca} / \mathrm{P}$ molar ratio.
Furthermore, all the calculated $s$ parameters are smaller than the value of 1 .

This result reveals that the ionic hopping conductivity is responsible for the conductivity mechanisms of the samples [24]. As can be understood from the above mentioned results, the phase composition affects the dielectric properties $[25,26]$.

\section{CONCLUSIONS}

The samples with different $\mathrm{Ca} / \mathrm{P}$ ratio were synthesized using sol-gel route. The effects of the change in the $\mathrm{Ca} / \mathrm{P}$ ratio on structural, morphological and dielectric properties of the samples were investigated. As a result of these processes, it has been reached the following conclusions. While the calcium phosphate $\left(\mathrm{Ca}_{2} \mathrm{P}_{2} \mathrm{O}_{7}\right)$ phase having tetragonal crystal structure is dominant for the lowest $\mathrm{Ca} / \mathrm{P}$ ratio, the major phase of calcium hydroxide $\left(\mathrm{Ca}(\mathrm{OH})_{2}\right)$ with hexagonal crystal structure are detected for the highest $\mathrm{Ca} / \mathrm{P}$ ratio. Hydroxyapatite $\left(\mathrm{Ca}_{10}\left(\mathrm{PO}_{4}\right)_{6}(\mathrm{OH})_{2}\right)$ with hexagonal crystal structure is the main crystalline phase for the $\mathrm{Ca} / \mathrm{P}$ molar ratio of 2,3 and 4 . The calculated values of the crystallite size, lattice parameters and volume of the unit cell are significantly affected by the $\mathrm{Ca} / \mathrm{P}$ ratio. The FTIR spectra support the XRD results. The morphologies of the samples, as expected, vary with the increasing $\mathrm{Ca} / \mathrm{P}$ ratio. The values of the relative permittivity, dielectric loss and alternating current conductivity are remarkably affected by the molar ratio of $\mathrm{Ca} / \mathrm{P}$ ranging from 1 to 8 .

\section{REFERENCES}

1. Dorozhkin, S.V. Calcium Orthophosphates: Applications in Nature, Biology, and Medicine. Pan Stanford, Singapore, 2012: p. 850.

http://dx.doi.org/10.1201/b12312

2. Boch, P., Niepce, J.C. Ceramic Materials: Processes, Properties and Applications. ISTE Ltd., London, 2007: pp. $493-517$. http://dx.doi.org/10.1002/9780470612415

3. Bose, S., Tarafder, S. Calcium Phosphate Ceramic Systems in Growth Factor and Drug Delivery for Bone Tissue Engineering: A Review Acta Biomaterialia 8 (4) 2012: pp. $1401-1421$ http://dx.doi.org/10.1016/j.actbio.2011.11.017

4. Vallet-Regi, M. Ceramics for Medical Applications Journal of the Chemical Society, Dalton Transactions 2 2001: pp. $97-108$. http://dx.doi.org/10.1039/b007852m

5. Brunner, T.J., Grass, R.N., Bohner, M., Stark, W.J. Effect of Particle Size, Crystal Phase and Crystallinity on the Reactivity of Tricalcium Phosphate Cements for Bone Reconstruction Journal of Materials Chemistry 17 2007: pp. $4072-4078$.

6. Ducheyne, P., Qiu, Q. Bioactive Ceramics: The Effect of Surface Reactivity on Bone Formation and Bone Cell Function Biomaterials $20(23-24)$ 1999: pp. $2287-2303$.

7. Moseke, C., Gbureck, U. Tetracalcium Phosphate: Synthesis, Properties and Biomedical Applications Acta Biomaterialia 6 (10) 2010: pp. 3815-3823. http://dx.doi.org/10.1016/j.actbio.2010.04.020 
8. LeGeros, R.Z., Lin, S., Rohanizadeh, R., Mijares, D., LeGeros, J.P. Biphasic Calcium Phosphate Bioceramics: Preparation, Properties and Applications Journal of Materials Science: Materials in Medicine 14 (3) 2003: pp. $201-209$.

9. Samavedi, S., Whittington, A.R., Goldstein, A.S. Calcium Phosphate Ceramics in Bone Tissue Engineering: A Review of Properties and Their Influence on Cell Behavior Acta Biomaterialia 9 (9) 2013: pp. 8037-8045.

10. Kanchana, P., Sekar, C. Influence of Sodium Fluoride on the Synthesis of Hydroxyapatite by Gel Method Journal of Crystal Growth 312 (6) 2010: pp. 808-816.

11. Kalita, S.J., Bhardwaj, A., Bhatt, H.A. Nanocrystalline Calcium Phosphate Ceramics in Biomedical Engineering Materials Science and Engineering: C 27 (3) 2007: pp. $441-449$.

12. Cullity, B.D., Stock, S.R. Elements of X-Ray Diffraction. Prentice-Hall Inc., Upper Saddle River, New Jersey, 2001: pp. $167-171$.

13. Kaygili, O., Tatar, C. The Investigation of Some Physical Properties and Microstructure of Zn-Doped Hydroxyapatite Bioceramics Prepared by Sol-Gel Method Journal of SolGel-Science and Technology 61 2012: pp. 296-309. http://dx.doi.org/10.1007/s10971-011-2627-0

14. Kaygili, O., Ates, T., Keser, S., Al-Ghamdi, A.A., Yakuphanoglu, F. Controlling of Dielectrical Properties of Hydroxyapatite by Ethylenediamine Tetraacetic Acid (EDTA) For Bone Healing Applications Spectrochimica Acta Part A: Molecular and Biomolecular Spectroscopy 129 2014: pp. $268-273$. http://dx.doi.org/10.1016/j.saa.2014.03.082

15. Jonscher, A.K. The 'Universal' Dielectric Response Nature 267 1977: pp. 673-679.

16. Pham, T.T.T., Nguyen, T.P., Pham, T.N., Vu, T.P., Tran, D.L., Thai, H., Dinh, T.M.T. Impact of Physical and Chemical Parameters on the Hydroxyapatite Nanopowder Synthesized by Chemical Precipitation Method Advances in Natural Sciences: Nanoscience and Nanotechnology 4 2013: pp. $1-9$.

17. Elkabouss, K., Kacimi, M., Ziyad, M., Ammar, S., Bozon-Verduraz, F. Cobalt-exchanged Hydroxyapatite
Catalysts: Magnetic Studies, Spectroscopic Investigations, Performance in 2-butanol and Ethane Oxidative Dehydrogenations Journal of Catalysis 226 (1) 2004: pp. 16-24.

18. Kavitha, M., $\quad$ Subramanian, R., $\quad$ Narayanan, R., Udhayabanu, V. Solution Combustion Synthesis and Characterization of Strontium Substituted Hydroxyapatite Nanocrystals Powder Technology 253 2014: pp. $129-137$.

19. Halperin, C., Mutchnik, S., Agronin, A., Molotskii, M., Urenski, P., Salai, M., Rosenman, G. Piezoelectric Effect in Human Bones Studied in Nanometer Scale Nano Letters 4 (7) 2004: pp. $1253-1256$.

20. Ciuchi, I.V., Olariu, C.S., Mitoseriu, L. Determination of Bone Mineral Volume Fraction Using Impedance Analysis and Bruggeman Model Materials Science and Engineering: B 178 (19) 2013: pp. 1296-1302.

21. Marino, A.A., Becker, R.O., Bachman, C.H. Dielectric Determination of Bound Water of Bone Physics in Medicine and Biology 12 (3) 1967: pp. 367-378.

22. Nagai, M., Nishino, T. Surface Conduction of Porous Hydroxyapatite Ceramics at Elevated-temperatures Solid State Ionics 28-30 (2) 1988: pp. 1456-1461.

23. Gittings, J.P., Bowen, C.R., Dent, A.C.E., Turner, I.G., Baxter, F.R., Chaudhuri, J.B. Electrical Characterization of Hydroxyapatite-based Bioceramics Acta Biomaterialia 5 (2) 2009: pp. $743-754$.

24. Bamzai, K.K., Suri, S., Singh, V. Synthesis, Characterization, Thermal and Dielectric Properties of Pure and Cadmium Doped Calcium Hydrogen Phosphate Materials Chemistry and Physics $135(1)$ 2012: pp. $158-167$.

25. Gregorio, R., Ueno, E.M. Effect of Crystalline Phase, Orientation and Temperature on the Dielectric Properties of Poly (Vinylidene Fluoride) (PVDF) Journal of Materials Science 34 (18) 1999: pp. 4489-4500. http://dx.doi.org/10.1023/A:1004689205706

26. Kaygili, O., Dorozhkin, S.V., Ates, T., Al-Ghamdi, A.A., Yakuphanoglu, F. Dielectric Properties of Fe Doped Hydroxyapatite Prepared by Sol-gel Method Ceramics International 40 (7) 2014: pp. 9395-9402. 